\title{
Terpenoids produced by actinomycetes: isolation, structural elucidation and biosynthesis of new diterpenes, gifhornenolones A and B from Verrucosispora gifhornensis YM28-088
}

\author{
Masato Shirai ${ }^{1}$, Masaaki Okuda ${ }^{1}$, Keiichiro Motohashi ${ }^{1}$, Masaya Imoto ${ }^{2}$, Kazuo Furihata ${ }^{3}$, Yoshihide Matsuo ${ }^{4,6}$, \\ Atsuko Katsuta ${ }^{5}$, Yoshikazu Shizuri ${ }^{5}$ and Haruo Seto ${ }^{1}$ \\ New terpenoids named gifhornenolones A (1) and B (2) were isolated from the culture broth of Verrucosispora gifhornensis \\ YM28-088, and their structures were established as hydroxylated isopimaradiene derivatives on the basis of extensive NMR and \\ MS spectral analyses. In addition, a known sesquiterpene compound cyperusol C (3) was isolated. The absolute configuration \\ of 1 was determined by nuclear Overhauser effect spectroscopy (NOESY) and CD spectra as $4 R, 5 S, 9 R, 10 S, 13 R$, and that \\ of 2 was determined by NOESY experiments as $3 R, 4 R, 5 R, 9 R, 10 S, 13 R$. Labeling experiments with $\left[1-{ }^{13} \mathrm{C}\right] \mathrm{glucose}$ and \\ $\left[U-{ }^{13} C_{6}\right.$ ]glucose confirmed that the MEP (2-C-methyl-D-erythritol-4-phosphate) pathway was used for the biosynthesis of \\ terpenoids in this organism. 1 showed potent inhibitory activity to the androgen receptor with an $\mathrm{IC}_{50}$ of $2.8 \mu \mathrm{g} \mathrm{mI} \mathrm{I}^{-1}$. \\ The Journal of Antibiotics (2010) 63, 245-250; doi:10.1038/ja.2010.30; published online 9 April 2010
}

Keywords: androgen receptor binding inhibitor; biosynthesis; cyperusol C; gifhornenolone; terpenoid; Verrucosispora gifhornensis

\section{INTRODUCTION}

Marine microorganisms capable to produce secondary metabolites, marine actinomycetes, in particular, are an attractive resource for screening for bioactive compounds. Indeed, novel compounds exhibiting antitumor and/or antibacterial activity have been isolated from marine actinomycetes. ${ }^{1}$ For instance, abyssomicin $\mathrm{C}$ isolated from Verrucosispora sp. showed antibacterial activity against Gram-positive bacteria including pathogenic Staphylococcus aureus strains as an inhibitor of the para-aminobenzoic acid biosynthesis pathway. ${ }^{2-4}$ In addition, proximicin A produced by the same strain was reported to show antitumor activities. ${ }^{5,6}$ Examples of bioactive metabolites isolated from the genus Verrucosispora were, however, quite limited presumably due to limited distribution of the genus Verrucosispora in the marine environment.

Previously, we carried out screening for terpenoids produced by actinomycetes and succeeded in isolation of several new derivatives such as oxaloterpins ${ }^{7}$ and napyradiomycins. ${ }^{8}$ In continuation of our work on the isolation of terpenoids of actinomycetes origin, ${ }^{9}$ we attempted to obtain terpenoids from the genus Verrucosispora. Because terpenoids are lipophilic in most case, we analyzed crude solvent extracts of fermentation broths of several strains of this genus and succeeded in the isolation of two new diterpenoids named gifhornenolones A (1) and B (2) together with a known compound, cyperusol C (3) (Figure 1) from Verrucosispora gifhornensis YM28-088.

\section{RESULTS AND DISCUSSION}

Fermentation, extraction and isolation

$V$. gifhornensis YM28-088 that was isolated from an ascidian collected in Hiroshima, Japan, was cultured at $28^{\circ} \mathrm{C}$ for 5 days by rotary shaking in $500 \mathrm{ml}$ baffled Erlenmeyer flasks containing $100 \mathrm{ml}$ of the culture medium. The broth was filtered and the broth filtrate was extracted with ethyl acetate (EtOAc). After removal of the solvent, we analyzed the residue extracted with EtOAc by thin layer chromatography (TLC) ( $n$-hexane-EtOAc (1:1) or $\mathrm{CHCl}_{3}-\mathrm{MeOH}$ $(10: 1)$, visualized by staining with vanillin- $\left.\mathrm{H}_{2} \mathrm{SO}_{4}\right)$. Spots appearing bright purple or violet on the TLC plate were selected as potential candidates for isolation. The mycelial cake was extracted with $60 \%$ aqueous acetone, and after removal of the solvent, the residual solution was extracted EtOAc and analyzed by TLC in the same manner as above.

\footnotetext{
${ }^{1}$ Department of Applied Biology and Chemistry, Faculty of Applied Bioscience, Tokyo University of Agriculture, Setagaya-ku, Tokyo, Japan; ${ }^{2}$ Faculty of Science and Technology, Keio University, Yokohama-shi, Kanagawa, Japan; ${ }^{3}$ Graduate School of Agricultural and Life Sciences, University of Tokyo, Bunkyo-ku, Tokyo, Japan; ${ }^{4}$ Marine Biotechnology Institute Co. Ltd., Heita, Kamaishi-shi, Iwate, Japan and ${ }^{5}$ Marine Biosciences, Kamaishi Research Laboratory, Kitasato University, Heita, Kamaishi, Iwate, Japan ${ }^{6}$ Current address: Suntory Holdings Limited, R\&D Planning Division, Wakayamadai, Shimamoto-cho, Mishima-gun, Osaka, 618-8503, Japan.

Correspondence: Professor Haruo Seto, Department of Applied Biology and Chemistry, Faculty of Applied Bioscience, Tokyo University of Agriculture, Setagaya-ku, Tokyo 156-8502, Japan.

E-mail: haseto@nodai.ac.jp

Received 21 January 2010; revised 5 March 2010; accepted 8 March 2010; published online 9 April 2010
} 


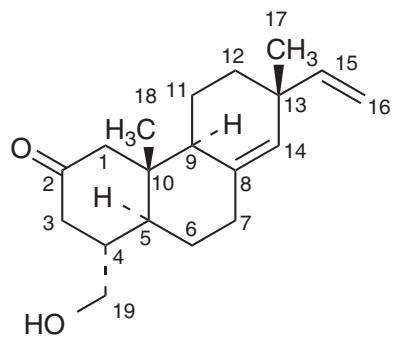

gifhornenolone A (1)

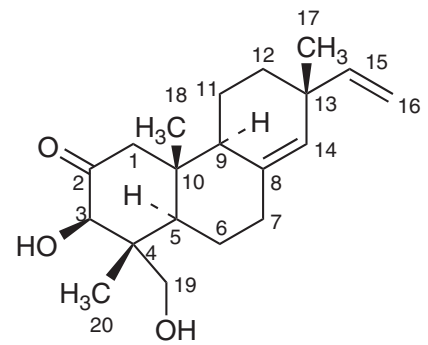

gifhornenolone B (2)

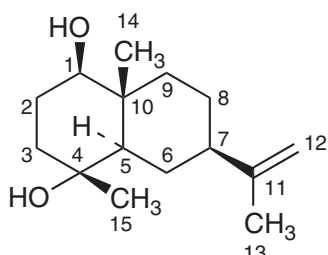

cyperusol C (3)

Figure 1 The structures of gifhornenolones A (1) and B (2), and cyperusol C (3).

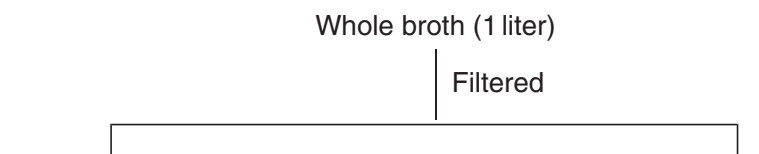

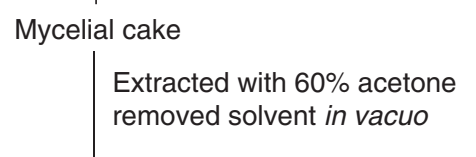

Silica gel column (Wakogel C-200)

Eluted with $n$-hexane-EtOAc (1:1)

HPLC

Eluted with $80 \%$ acetonitrile

Gifhornenolone A (0.4 mg) Gifhornenolone B (0.1 mg)
Filtrate

Extracted with EtOAc

Silica gel column (Wakogel C-200)

Eluted with $n$-hexane-EtOAc (1:1)

HPLC

Eluted with $50 \%$ acetonitrile

Cyperusol C (1.0 mg)

Scheme 1 Isolation and purification of gifhornenolones A (1) and B (2), and cyperusol C (3).

Semi-preparative purification of these positive spots was carried out by Si-gel column chromatography and C-18 reverse-phase high-performance liquid chromatography (RP-HPLC) (Scheme 1). The purified samples thus obtained were analyzed by ${ }^{1} \mathrm{H}$ NMR and fractions showing that methyl signals at around $\delta 1.0$ were assumed to contain terpenoids ${ }^{7,8}$, because almost all terpenoids possess several methyl groups. As a result of this screening, two fractions showing 2 or 3 methyl proton singlets were expected as terpenoids and subjected to detailed NMR analysis. NMR studies including COSY, HSQC and constant time-HMBC ${ }^{10}$ (CT-HMBC) experiments, as well as HR-MS and IR, were used to determine the structures of the following terpenoids, gifhornenolones A (1) and B (2) from the mycelial cake extracts and cyperusol C (3) from the broth filtrate (Figure 1). (See Supplementary information for ${ }^{1} \mathrm{H}$ NMR, ${ }^{13} \mathrm{C}$ NMR, COSY, HSQC, CT-HMBC, nuclear Overhauser effect spectroscopy (NOESY), HRMS, IR, LC-NMR of gifhornenolone A (1), B (2) and cyperusol C (3).)

\section{Structure elucidation}

Gifhornenolone A (1) was isolated as colorless needles. Its molecular formula was established as $\mathrm{C}_{19} \mathrm{H}_{28} \mathrm{O}_{2}$ by HR-MS $(\mathrm{m} / z 289.2145[\mathrm{M}+$ $\mathrm{H}]^{+}$, calcd 289.2168) indicating six degrees of unsaturation. The IR spectrum of 1 showed a ketone group $\left(1701 \mathrm{~cm}^{-1}\right)$ and a hydroxyl group $\left(3421 \mathrm{~cm}^{-1}\right)$ revealing the oxygen containing functionalities in 1. The ${ }^{13} \mathrm{C}$ NMR and HSQC spectra confirmed the presence of 19 carbons (Table 1), including one ketone $\left(\delta_{\mathrm{C}} 210.6(\mathrm{C}-2)\right)$, four olefinic carbons $\left(\delta_{\mathrm{C}} 148.3(\mathrm{C}-15), 135.4(\mathrm{C}-8), 130.0(\mathrm{C}-14)\right.$ and 110.6 (C-16)), one oxymethylene carbon $\left(\delta_{\mathrm{C}} 63.9\right.$ (C-19)), three methine carbons $\left(\delta_{\mathrm{C}} 47.8(\mathrm{C}-9), 45.0(\mathrm{C}-5)\right.$ and 40.9 (C-4)), six methylene carbons $\left(\delta_{\mathrm{C}} 53.4(\mathrm{C}-1), 44.2(\mathrm{C}-3), 34.7\right.$ (C-7), 34.1 (C-12), 25.2 (C-6) and $19.1(\mathrm{C}-11))$, two singlet methyl groups $\left(\delta_{\mathrm{C}} 26.2(\mathrm{C}-17)\right.$ and 14.1 $(\mathrm{C}-18))$ and two quaternary carbons $\left(\delta_{\mathrm{C}} 42.8(\mathrm{C}-10)\right.$ and 37.4 (C-13)). Further structural information on $\mathbf{1}$ was obtained by analyzing HSQC, CT-HMBC and COSY spectra.

The singlet methyl protons $\mathrm{H}-17$ showed ${ }^{1} \mathrm{H}_{-}{ }^{13} \mathrm{C}$ long-range couplings to C-12, C-13, C-14 and C-15, and the singlet methyl protons $\mathrm{H}-18$ were coupled to C-1, C-5, C-9 and C-10 in the CT-HMBC spectrum. Partial structural information around the oxymethylene protons $\mathrm{H}-19$ was obtained by its coupling to C-3, C-4 and C-5. The deshielded methylene protons $\mathrm{H}-1$ and $\mathrm{H}-3$ were connected to the carbonyl carbon by their couplings to C-2. The olefinic proton $\mathrm{H}-14$ was coupled to C-7 and C-9 in addition to the C-8 sp ${ }^{2}$ carbon. The exomethylene protons $\mathrm{H}-16$ were coupled to an $\mathrm{sp}^{2}$ carbon $\mathrm{C}-15$ revealing the presence of a vinyl residue. This partial structure was corroborated by COSY correlations between $\mathrm{H}-15$ and $\mathrm{H}-16$. The quaternary sp ${ }^{2}$ carbon C-8 was coupled to H-6, H-7, H-9 and H-11. In addition, COSY correlations were observed between $\mathrm{H}-19$ and $\mathrm{H}-7$ through $\mathrm{H}-4, \mathrm{H}-5$ and $\mathrm{H}-6$, and between $\mathrm{H}-9$ and $\mathrm{H}-12$ through $\mathrm{H}-11$. These results revealed the presence of an isopimaradiene skeleton in $\mathbf{1}$.

The relative configuration of $\mathbf{1}$ was established by analysis of proton coupling constants and NOESY experiments as summarized in Figure 3 . The stereochemistry at C-4 could not be determined directly by the splitting pattern of $\mathrm{H}-4$ (1.77 p.p.m., $\mathrm{m}$ ) due to its overlapping with H-6eq (1.77 p.p.m., m). However, H-5 at 1.74 p.p.m. (ddd, $J=11.3,11.3$ and $3.5 \mathrm{~Hz}$ ) gave satisfactory information. This proton was coupled with H-6eq (1.77 p.p.m., m) and H-6ax (1.17 p.p.m., dddd, $J=4.5,11.3,13.5$ and $13.5 \mathrm{~Hz}$ ). Thus, the coupling constant between $\mathrm{H}-5$ and $\mathrm{H}-6 \mathrm{ax}$ was determined to be $11.3 \mathrm{~Hz}$ suggesting $\mathrm{H}-5$ is in axial orientation. The remaining coupling constant $J=11.3 \mathrm{~Hz}$ 
Table $1{ }^{13} \mathrm{C}$ - and ${ }^{1} \mathrm{H}$-NMR spectral data for 1 and 2

\begin{tabular}{|c|c|c|c|c|c|c|c|}
\hline \multirow[b]{2}{*}{ C } & \multicolumn{4}{|c|}{1} & \multicolumn{3}{|c|}{2} \\
\hline & & $\delta\left({ }^{13} C\right)$ & $\delta\left({ }^{1} H\right)$ & Multiplicity $^{a}$ & $\delta\left({ }^{13} C\right)$ & $\delta\left({ }^{1} H\right)$ & Multiplicity $^{a}$ \\
\hline 1 & $\mathrm{CH}_{2}$ & 53.4 & $2.15^{b}$ & $d(13.1)$ & 51.0 & 2.24 & $d(10.0)$ \\
\hline & $2.42^{c}$ & dd $(13.1,2.3)$ & & 2.47 & $d(10.0)$ & & \\
\hline 2 & C & 210.6 & & & 211.6 & & \\
\hline 3 & $\mathrm{CH}_{2}$ & 44.2 & $\begin{array}{l}2.38^{c} \\
2.46^{b}\end{array}$ & $\begin{array}{l}\text { ddd }(14.0,4.5,2.3) \\
\quad \text { dd }(14.0,12.9)\end{array}$ & $77.2^{\mathrm{d}}$ & 4.35 & $\mathrm{~m}$ \\
\hline 4 & $\mathrm{CH}$ & 40.9 & 1.77 & $\mathrm{~m}$ & $49.2^{\mathrm{e}}$ & & \\
\hline 5 & $\mathrm{CH}$ & 45.0 & 1.74 & ddd $(11.3,11.3,3.5)$ & 45.2 & 2.05 & $\mathrm{dd}(10.5,2.5)$ \\
\hline 6 & $\mathrm{CH}_{2}$ & 25.2 & $\begin{array}{l}1.17^{b} \\
1.77^{c}\end{array}$ & $\begin{array}{c}\text { dddd }(13.5,13.5,11.3,4.5) \\
m\end{array}$ & 21.9 & $\begin{array}{l}1.41 \\
1.64\end{array}$ & $\begin{array}{l}m \\
m\end{array}$ \\
\hline 7 & $\mathrm{CH}_{2}$ & 34.7 & $\begin{array}{l}2.13^{b} \\
2.29^{c}\end{array}$ & $\begin{array}{l}\text { ddd }(13.5,13.5,2.0) \\
\text { ddd }(13.5,4.5,2.0)\end{array}$ & 35.0 & $\begin{array}{l}2.11^{b} \\
2.26^{c}\end{array}$ & $\begin{array}{c}\mathrm{m} \\
\mathrm{ddd}(12.0,4.0,1.5)\end{array}$ \\
\hline 8 & C & 135.4 & & & 135.3 & & \\
\hline 9 & $\mathrm{CH}$ & 47.8 & 2.00 & $\mathrm{dd}(7.6,7.6)$ & 50.2 & 2.01 & $\mathrm{dd}(6.5,6.5)$ \\
\hline 10 & C & 42.8 & & & 44.8 & & \\
\hline 11 & $\mathrm{CH}_{2}$ & 19.1 & $1.50,1.54$ & $\mathrm{~m}$ & 18.8 & $1.50,1.54$ & $\mathrm{~m}$ \\
\hline 12 & $\mathrm{CH}_{2}$ & 34.1 & $\begin{array}{l}1.40^{\mathrm{b}} \\
1.43^{\mathrm{c}}\end{array}$ & $\begin{array}{c}\text { ddd }(15.0,11.0,4.0) \\
m\end{array}$ & 34.1 & $\begin{array}{l}1.37 \\
1.43\end{array}$ & $\begin{array}{c}\text { ddd }(14.0,11.0,3.5) \\
m\end{array}$ \\
\hline 13 & $\mathrm{C}$ & 37.4 & & & 37.4 & & \\
\hline 14 & $\mathrm{CH}$ & 130.0 & 5.30 & br s & 130.1 & 5.24 & br s \\
\hline 15 & $\mathrm{CH}$ & 148.3 & 5.76 & $\mathrm{dd}(17.5,10.0)$ & 148.3 & 5.69 & dd $(15.0,9.5)$ \\
\hline 16 & $\mathrm{CH}_{2}$ & 110.6 & $\begin{array}{l}4.90 \\
4.92\end{array}$ & $\begin{array}{l}\text { dd }(10.0,1.5) \\
\text { de }(17.5,1.5)\end{array}$ & 110.6 & $\begin{array}{l}4.84 \\
4.85\end{array}$ & $\begin{array}{l}\text { dd }(9.5,1.5) \\
\text { dd }(15.0,1.5)\end{array}$ \\
\hline 17 & $\mathrm{CH}_{3}$ & 26.2 & 1.03 & $\mathrm{~s}$ & 26.1 & 0.98 & $\mathrm{~s}$ \\
\hline 18 & $\mathrm{CH}_{3}$ & 14.1 & 0.71 & $\mathrm{~s}$ & 16.0 & 0.77 & $\mathrm{~s}$ \\
\hline 19 & $\mathrm{CH}_{2}$ & 63.9 & $\begin{array}{l}3.61 \\
3.80\end{array}$ & $\begin{array}{l}\text { dd }(11.0,2.5) \\
\text { dd }(11.0,4.4)\end{array}$ & 66.0 & $\begin{array}{l}3.44 \\
3.49\end{array}$ & $\begin{array}{l}d(9.0) \\
d(9.0)\end{array}$ \\
\hline 20 & $\mathrm{CH}_{3}$ & & & & 12.9 & 0.55 & $\mathrm{~s}$ \\
\hline
\end{tabular}

NMR spectra were taken in $\mathrm{CDCl}_{3}$

aJ in $\mathrm{Hz}$.

${ }^{\mathrm{b}} \mathrm{CH}$.

${ }^{\mathrm{C}} \mathrm{C}$.

${ }^{\mathrm{C}} \mathrm{C}$.

eEquatorial.

of $\mathrm{H}-5 \mathrm{ax}$ was assigned to the coupling with $\mathrm{H}-4$ suggesting the stereochemistry at $\mathrm{H}-4$ to be axial. This conclusion was also supported by the splitting pattern of $\mathrm{H}-3 \mathrm{ax}(12.9$ and $14.0 \mathrm{~Hz}$, the latter was assigned to geminal coupling to $\mathrm{H}-3 \mathrm{eq}$ ).

NOE correlations were observed between $\mathrm{H}-4$ and $\mathrm{H}-18, \mathrm{H}-18$ and $\mathrm{H}-11 \mathrm{ax}$, and $\mathrm{H}-11 \mathrm{ax}$ and $\mathrm{H}-17$ suggesting all these protons to be in axial orientation. In addition, H-5 showed an NOE to H-9.

The absolute configuration of $\mathbf{1}$ was clarified by measurement of the CD spectrum that exhibited a positive Cotton effect at $289 \mathrm{~nm}$. Application of the octant rule to this positive Cotton effect clearly indicated that the axial methyl group C-18 is located in the upper left back octant. Consequently, the absolute configurations of the stereogenic centers of 1 were established as $4 R, 5 S, 9 R, 10 S, 13 R$.

The molecular formula of gifhornenolone $\mathrm{B}(2)$ was established as $\mathrm{C}_{20} \mathrm{H}_{30} \mathrm{O}_{3}$ by HR-MS measurement $\left(\mathrm{m} / \mathrm{z} 319.2270[\mathrm{M}+\mathrm{H}]^{+}\right.$, calcd 319.2273). The ${ }^{13} \mathrm{C}$ NMR and HSQC spectra confirmed the presence of 20 carbons in 2 . Its NMR data were similar to those of $\mathbf{1}$ (Table 1 ) except for large downfield shifts of the oxymethine carbon $\left(\delta_{\mathrm{C}} 77.2\right.$ $(\mathrm{C}-3))$ and one quaternary carbon $\left(\delta_{\mathrm{C}} 49.2(\mathrm{C}-4)\right)$ with appearance of an additional methyl carbon $\left(\delta_{\mathrm{C}} 12.9(\mathrm{C}-20)\right)$. Further structural information on 2 was obtained by analyzing CT-HMBC and COSY spectra (Figure 2). Assuming the same stereochemistries for the gross structures of $\mathbf{1}$ and 2, the stereochemistry at C-3 of $\mathbf{2}$ was concluded to be $R$ by observation of NOE between $\mathrm{H}-3$ and $\mathrm{H}-5$ as shown in Figure 3.

Cyperusol C (3) was obtained as a colorless oil. Its NMR spectral data summarized in experimental section were in agreement with those reported for the known compound. ${ }^{11}$ The absolute configuration of this compound was confirmed by NOESY experiments and negative optical rotatory dispersion (ORD) spectrum as summarized in Figure 3 as $3 R, 4 R, 5 R, 9 R, 10 S, 13 R .3$ was first purified from a plant Cyperus longus, but its isolation from microorganisms has never been reported.

\section{Biosynthesis of isopentenyl diphosphate}

Isopentenyl diphosphate, the starting material for the biosynthesis of terpenoids, is known to be biosynthesized mostly through the MEP (2-C-methyl-D-erythritol-4-phosphate) pathway ${ }^{12}$ with some exceptions through the classical mevalonate pathway in actinomycetes. The latter examples include naphterpin, ${ }^{13}$ terpentecin, ${ }^{14}$ napyradiomycin ${ }^{15}$ and BE-40644 ${ }^{16}$. To examine which pathway was used in $V$. gifhornensis YM28-088, we carried out ${ }^{13} \mathrm{C}$-labeling experiments with 1 and 3.

Addition of $\left[1-{ }^{13} \mathrm{C}\right]$ glucose to the fermentation broth of V. gifhornensis $\mathrm{YM} 28-088$ increased the signal intensities of $\mathrm{C}-2$, C-6, C-11, C-14, C-16, C-17, C-18 and C-19 of 1 by approximately 


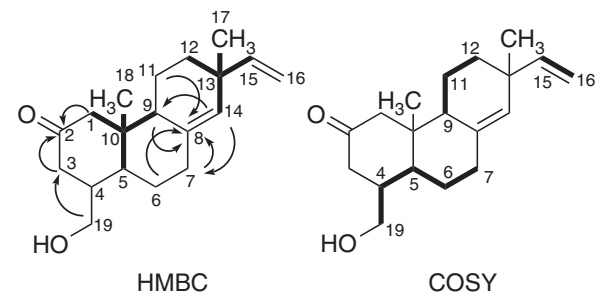

gifhornenolone $\mathrm{A}(\mathbf{1})$
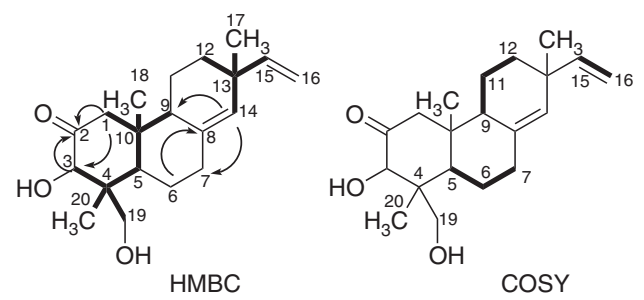

gifhornenolone B (2)

Figure 2 Important ${ }^{1} \mathrm{H}_{-}{ }^{13} \mathrm{C}$ CT-HMBC correlations observed for gifhornenolones A (1) and B (2). Bold lines show HMBC correlations observed with methyl protons, or COSY correlations.

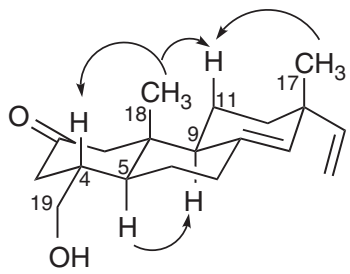

gifhornenolone A (1)

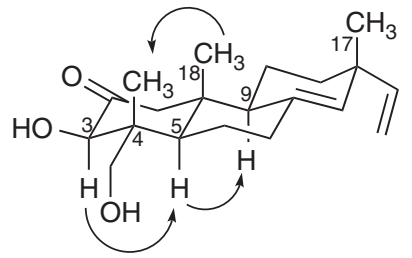

gifhornenolone B (2)

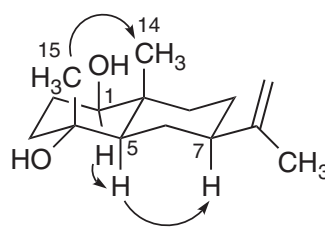

cyperusol C (3)

Figure 3 NOEs observed for gifhornenolones A (1) and B (2), and cyperusol C (3).

two times (Table 2). In 1 labeled with $\left[U_{-}{ }^{13} \mathrm{C}_{6}\right]$ glucose, eight pairs of ${ }^{13} \mathrm{C}-{ }^{13} \mathrm{C}$ couplings were observed between $\mathrm{C}-2$ and $\mathrm{C}-3, \mathrm{C}-4$ and $\mathrm{C}-19$, C-5 and C-6, C-8 and C-14, C-9 and C-11, C-10 and C-18, C-13 and $\mathrm{C}-17$, and $\mathrm{C}-15$ and $\mathrm{C}-16$ leaving three enhanced singlet peaks due to C-1, C-7 and C-12. These labeling patterns of 1 were explained by operation of the MEP pathway in V. gifhornensis YM28-088 (Figure 4). In agreement with these results, no incorporation of sodium $\left[1-{ }^{13} \mathrm{C}\right]$ acetate was observed with $\mathbf{1}$ (data not shown).

Assuming that $\mathbf{2}$ is a biosynthetic intermediate for $\mathbf{1}$ and that the carbon skeleton of gifhornenolone is formed by cyclization by chair-chair conformation of geranylgeranyl diphosphate, the biosynthetic scheme for $\mathbf{1}$ can be summarized as shown in Figure 5. At first, the $\beta$-methyl group of $\mathbf{2}$ is oxidized to carboxylic acid presumably by $\mathrm{P} 450$, and then the intermediate is converted to its 2-keto etc. by tautomerization to the 3-keto derivative that is very easily decarboxylated to give an enol derivative. After enolization, we converted the resultant 3-keto intermediate to 2-keto-3-hydroxy derivative by tautomerization. Finally, removal of the alcohol at C-3 may be carried out by dehydration and hydrogenation to give $\mathbf{1}$.

In 3, the signal intensities of C-2, C-6, C-8 and C-13 to 15 were enhanced by about 2.6 -fold by the addition of $\left[1-{ }^{13} \mathrm{C}\right]$ glucose. When labeled with $\left[U_{-}{ }^{13} \mathrm{C}_{6}\right]$ glucose, six pairs of ${ }^{13} \mathrm{C}_{-}{ }^{13} \mathrm{C}$ couplings were detected between C-1 and C-2, C-4 and C-15, C-5 and C-6, C-7 and C-8, C-10 and C-14, and C-11 and C-13 with enriched singlet peaks of C-3, C-9 and C-12 (Table 2).

\section{Biological activity}

Because isopimarane-type diterpenes have structural similarity to steroidal compounds such as dihydrotestosterone (DHT) and other known androgen antagonists, we expected that 1 might show androgen antagonist activity. 1 showed inhibitory activity against binding of DHT to AR (androgen receptor) with an $\mathrm{IC}_{50}$ of $9.7 \mu \mathrm{M} \mathrm{ml}^{-1}$ (in vitro binding assay, using $\left[{ }^{3} \mathrm{H}\right]$-DHT and recombinant AR).
Table 2 Incorporation of $\left[1-{ }^{13} \mathrm{C}\right] g$ lucose and $\left[\mathrm{U}-{ }^{13} \mathrm{C}_{6}\right]$ glucose into 1 and 3

\begin{tabular}{|c|c|c|c|c|c|c|}
\hline \multirow[b]{2}{*}{ Position } & \multicolumn{3}{|c|}{1} & \multicolumn{3}{|c|}{3} \\
\hline & $\delta_{C}$ & {$\left[1-{ }^{13} C\right] g l u c o s e^{a}$} & $J_{-C-C}{ }^{b}$ & $\delta_{C}$ & {$\left[1-{ }^{13} C\right] g / u \operatorname{cose} e^{a}$} & $J_{-C}-C^{b}$ \\
\hline 1 & 53.4 & 1.0 & & 79.5 & 1.0 & 36.5 \\
\hline 2 & 210.6 & 2.4 & 38.5 & 28.6 & 2.7 & 36.7 \\
\hline 3 & 44.2 & 1.1 & 38.3 & 40.9 & 1.0 & \\
\hline 4 & 40.9 & 1.1 & 37.7 & 71.6 & 1.6 & 37.4 \\
\hline 5 & 45.0 & 1.2 & 34.1 & 53.0 & 1.0 & 34.6 \\
\hline 6 & 25.2 & 2.3 & 37.7 & 25.8 & 2.6 & 34.6 \\
\hline 7 & 34.7 & 1.3 & & 45.7 & 0.9 & 32.5 \\
\hline 8 & 135.4 & 1.0 & 71.3 & 26.4 & 2.7 & 32.8 \\
\hline 9 & 47.8 & 0.8 & 35.6 & 40.6 & 1.0 & \\
\hline 10 & 42.8 & 1.0 & 36.3 & 39.0 & 1.5 & 36.0 \\
\hline 11 & 19.1 & 2.4 & 35.0 & 150.3 & 1.5 & 41.3 \\
\hline 12 & 34.1 & 1.0 & & 108.4 & 1.1 & \\
\hline 13 & 37.4 & 1.1 & 35.6 & 21.0 & 2.6 & 41.0 \\
\hline 14 & 130.0 & 2.2 & 72.2 & 13.0 & 2.7 & 36.1 \\
\hline 15 & 148.3 & 1.1 & 69.7 & 22.8 & 2.7 & 37.5 \\
\hline 16 & 110.6 & 2.3 & 70.2 & & & \\
\hline 17 & 26.2 & 2.0 & 35.5 & & & \\
\hline 18 & 14.1 & 2.0 & 36.4 & & & \\
\hline 19 & 63.9 & 1.9 & 38.5 & & & \\
\hline
\end{tabular}

apeak intensities were normalized to $\mathrm{C}-1$ carbon in both the compounds.

${ }^{b}$ Carbon-carbon coupling constants observed with samples labeled by $\left[{ }^{13} \mathrm{C}_{6}\right]$ glucose.

\section{EXPERIMENTAL SECTION}

General experimental procedures

Both $1 \mathrm{D}{ }^{1} \mathrm{H}$ and ${ }^{13} \mathrm{C}$ NMR spectra were recorded on a JEOL Alpha 400 NMR spectrometer (JEOL, Akishima, Tokyo, Japan, operating at $400 \mathrm{MHz}$ for ${ }^{1} \mathrm{H}$ and $100 \mathrm{MHz}$ for ${ }^{13} \mathrm{C}$ ) or a Varian Inova 500 (Varian, Palo Alto, CA, USA, 


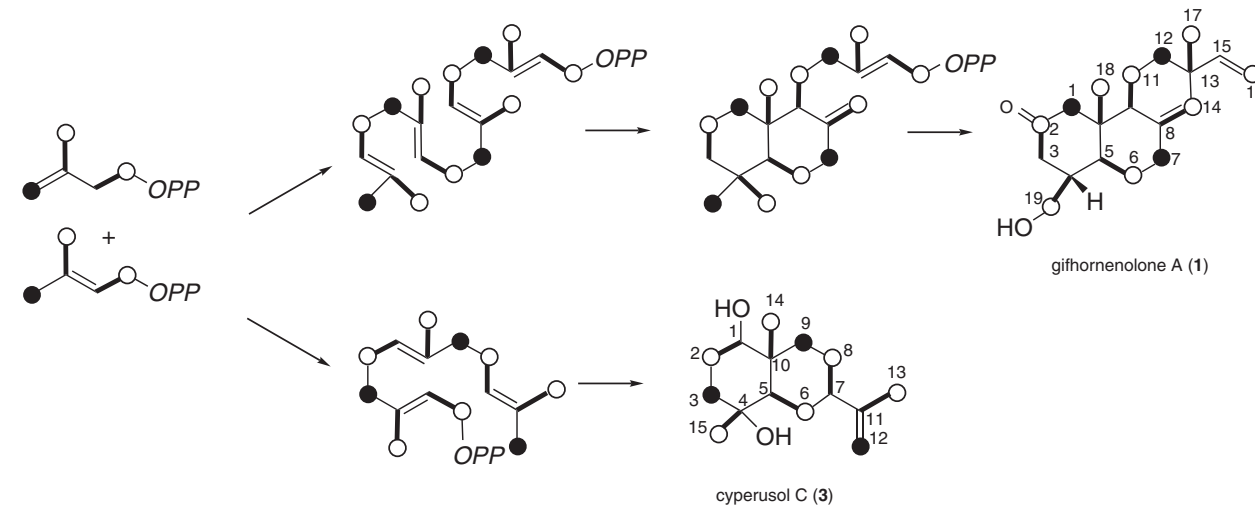

Figure 4 Incorporation patterns of isopentenyl diphosphate (IPP) from $\left[1-{ }^{13} \mathrm{C}\right] \mathrm{glucose}$ and $\left[\mathrm{U}^{13} \mathrm{C}_{6}\right]$ glucose into gifhornenolones $\mathrm{A}(\mathbf{1})$ and cyperusol $\mathrm{C}(\mathbf{3})$. Open circles show carbons derived from $\left[1-{ }^{13} \mathrm{C}\right] g$ lucose through the MEP pathway. Closed circles indicate carbons derived from C-3 of pyruvic acid. Bold lines show ${ }^{13} \mathrm{C}-13 \mathrm{C}$ couplings observed with a sample enriched by $\left[\mathrm{U}_{-}{ }^{13} \mathrm{C}_{6}\right]$ glucose.<smiles>C=CC1(C)CCC2=CCC3C(C)(CO)C(O)C(=O)CC3(C)C2CC1</smiles><smiles>C/C=C\C1(C)C=C2CCC3(C)C(C(=O)O)C(O)C(=O)CC3(C)C2CC1</smiles>

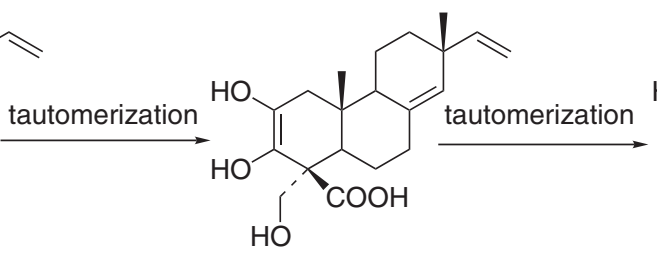<smiles>C=CC1(C)C=C2CCC3C(C(=O)O)(C(=O)O)C(=O)C(O)CC3(C)C2CC1</smiles><smiles>C=CC1(C)C=C2CCC3C(CO)=C(O)C(O)CC3(C)C2CC1</smiles><smiles>C/C=C\C1(C)CCC2CCCC=C2CCC1CO</smiles><smiles>CC=C1CCC2CC3(CC(=O)C(O)C2CO)C1CCC3(C)/C=C\C</smiles><smiles>C=CC1(C)C=C2CCC3C(CO)CC(=O)CC3(C)C2CC1</smiles>

Figure 5 Hypothetical biosynthetic pathway from gifhornenolone B (2) to gifhornenolone A (1).

operating at $500 \mathrm{MHz}$ for ${ }^{1} \mathrm{H}$ and $125 \mathrm{MHz}$ for ${ }^{13} \mathrm{C}$ ). Two-dimensional ${ }^{1} \mathrm{H}-{ }^{1} \mathrm{H}$ COSY, NOESY, ${ }^{1} \mathrm{H}_{-}{ }^{13} \mathrm{C}$ HSQC, CT-HMBC spectra were recorded on a Varian Inova 500 or JEOL ECA 600 NMR spectrometer. Samples were dissolved in $\mathrm{CDCl}_{3}$ and the solvent peak was used as an internal standard $\left(\delta_{\mathrm{H}} 7.24\right.$ and $\delta_{\mathrm{C}}$ 77.0). HR-ESI-MS data were recorded on a Waters LCT-Premier XE mass spectrometer (Waters, Milford, MA, USA). IR spectra were obtained in $\mathrm{KBr}$ with a Shimadzu 8300 FTIR spectrometer (Shimadzu, Kyoto, Japan). Optical rotations were measured on a HORIBA SEPA-300 polarimeter (HORIBA, Kyoto, Japan). CD spectra were recorded on a Jasco J-720WI spectropolarimeter with ORDM-306 attachment (Jasco, Tokyo, Japan). ORD spectra were obtained with a Jasco J-720WI (cylindrical quartz cell $\phi 3.5 \times 100 \mathrm{~mm}$ ). HPLC purifications were carried out using a SENSHU PAK PEGASIL ODS column $(20 \times 250 \mathrm{~mm})$ equipped with a Hitachi High Technologies L-2450 diode array detector (Hitachi, Ibaraki, Japan). Wako Wakogel C-200 was used for Si gel column chromatography (Wako, Osaka, Japan); Si gel $60 \mathrm{~F}_{254}$ plastic-backed sheets were used for TLC analysis.

\section{Cultivation of $V$. gifhornensis YM28-088}

V. gifhornensis YM28-088 was inoculated with the mycelia of the strain grown on an agar slant into $15 \mathrm{ml}$ test tubes containing $5 \mathrm{ml}$ of a preliminary seed medium consisting of soluble starch $1.0 \%$, polypeptone $1.0 \%$, molasses $1.0 \%$ and meat extract $1.0 \%$ ( $\mathrm{pH} 7.2$ before sterilization), and was cultured at $28{ }^{\circ} \mathrm{C}$ for 7 days on a rotary shaker at 170 r.p.m. Aliquot $(1 \mathrm{ml})$ of the seed culture was inoculated into each of $500 \mathrm{ml}$ baffled Erlenmeyer flasks containing $100 \mathrm{ml}$ of the medium consisting of starch $2.0 \%$, polypeptone $0.5 \%$, meat extract $0.5 \%$, dry yeast $0.3 \%$ and $\mathrm{CaCO}_{3} 0.3 \%$ (pH 7.0 before sterilization). The microorganism was cultured at $28^{\circ} \mathrm{C}$ for 5 days. This strain is maintained at Marine Biosciences, Kamaishi Research Laboratory, Kitasato University, Heita, Kamaishi, Iwate, Japan.

Purification of gifhornenolones A (1) and B (2)

The fermentation broth (1 liter) was separated into mycelial cake and filtrate by suction filtration. The supernatant was extracted with an equal amount of EtOAc, the organic layer was dried over anhydrous $\mathrm{Na}_{2} \mathrm{SO}_{4}$ and the solvent was removed under reduced pressure. After mycelial cake was submerged in $60 \%$ acetone-water, we removed the solvent under reduced pressure, and extracted the aqueous residue with an equal amount of EtOAc.

The EtOAc extract from the mycelia cake was subjected to Si gel column chromatography ( $n$-hexane-EtOAc, 1:1). The eluted fractions were analyzed by color reaction with vanillin- $\mathrm{H}_{2} \mathrm{SO}_{4}$ on $\mathrm{Si}$ gel TLC $\left(\mathrm{CHCl}_{3}-\mathrm{MeOH}, 10: 1\right)$. Fractions containing 1 and 2 ( $\mathrm{Rf} 0.4$ ) were combined and further purified by ODS HPLC $(20 \times 250 \mathrm{~mm}$; SENSHU PAK PEGASIL ODS $)$ with a PDA detector eluted with $\mathrm{CH}_{3} \mathrm{CN}$ in $\mathrm{H}_{2} \mathrm{O}(80 \%)$ at a flow rate of $14 \mathrm{ml} \mathrm{min}^{-1}$ to yield $1\left(0.4 \mathrm{mgl}^{-1}, 9.7 \mathrm{~min}\right)$ and $2\left(0.1 \mathrm{mgl}^{-1}, 10.1 \mathrm{~min}\right)$.

Gifhornenolone A (1). Colorless needles, m.p. $94-95^{\circ} \mathrm{C}$ (crystallized from AcOEt $-n$-hexane $),[\alpha]_{D}^{25}+6.6^{\circ}\left(c \quad 0.18, \mathrm{CHCl}_{3}\right), \mathrm{CD}(c=1.7, \mathrm{MeOH})$ : $\Delta \varepsilon=-14.35$ (210 nm, neg. max.) $\Delta \varepsilon=+2.0$ ( $289 \mathrm{~nm}$, pos. max.), IR ( $\mathrm{KBr})$ $1701,3422 \mathrm{~cm}^{-1} ;{ }^{1} \mathrm{H}$ NMR $\left(400 \mathrm{MHz}, \mathrm{CDCl}_{3}\right)$ and ${ }^{13} \mathrm{C}$ NMR $(100 \mathrm{MHz}$, $\mathrm{CDCl}_{3}$ ), see Table 1; HR-MS $m / z 289.2145$ (calcd for $\mathrm{C}_{19} \mathrm{H}_{28} \mathrm{O}_{2}$, $[\mathrm{M}+\mathrm{H}]^{+}$ 289.2168). 
Gifhornenolone B (2). Colorless oil, ${ }^{1} \mathrm{H}$ NMR $\left(400 \mathrm{MHz}, \mathrm{CDCl}_{3}\right)$ and ${ }^{13} \mathrm{C}$ NMR $\left(100 \mathrm{MHz}, \mathrm{CDCl}_{3}\right.$ ), see Table 1; HR-MS m/z 319.2270 (calcd for $\left.\mathrm{C}_{19} \mathrm{H}_{28} \mathrm{O}_{2},[\mathrm{M}+\mathrm{H}]^{+} 319.2273\right)$.

Purification of cyperusol C (3). The EtOAc extract from the filtrate of $V$. gifhornensis YM28-088 was subjected to $\mathrm{Si}$ gel column chromatography ( $n$-hexane-EtOAc, 1:2). 3 was visualized by color reaction with vanillin- $\mathrm{H}_{2} \mathrm{SO}_{4}$ on Si gel TLC ( $n$-hexane-EtOAc, 1:1). Fractions containing cyperusol C ( $\operatorname{Rf} 0.2)$ were combined and further purified by ODS HPLC $(20 \times 250 \mathrm{~mm}$; SENSHU PAK PEGASIL ODS) with a PDA detector eluted with $\mathrm{CH}_{3} \mathrm{CN}$ in $\mathrm{H}_{2} \mathrm{O}(50 \%)$ at a flow rate of $14 \mathrm{ml} \mathrm{min}^{-1}$ to yield cyperusol C $\left(1.0 \mathrm{mgl}^{-1}, 8.8 \mathrm{~min}\right)$.

Cyperusol C (3). Colorless oil, ${ }^{1} \mathrm{H}$ NMR data, $\delta_{\mathrm{H}} 0.89,1.12,1.74$ (3H each, s, $\left.\mathrm{H}_{3}-14,15,13\right), 1.14$ ( $1 \mathrm{H}$, ddd, $\left.J=4.0,13.0,13.5 \mathrm{~Hz}, \mathrm{H}-9\right), 1.88$ ( $1 \mathrm{H}, \mathrm{ddd}, J=3.5$, $3.5,13.5 \mathrm{~Hz}, \mathrm{H}-9), 1.26,1.84$ (1H each, both $\mathrm{m}, \mathrm{H}-6), 1.28(1 \mathrm{H}, \mathrm{m}, \mathrm{H}-5), 1.38$ (1H, dddd, $J=3.5,13.0,13.5,17.0 \mathrm{~Hz}, \mathrm{H}-8), 1.52(1 \mathrm{H}$, ddd, $J=3.5,12.0$, $13.5 \mathrm{~Hz}, \mathrm{H}-3), 1.62(1 \mathrm{H}, \mathrm{m}, \mathrm{H}-8), 1.60,1.72$ (1H each, both $\mathrm{m}, \mathrm{H}-2), 1.80$ $(1 \mathrm{H}, \mathrm{ddd}, J=3.0,3.5,12.0 \mathrm{~Hz}, \mathrm{H}-3), 1.92(1 \mathrm{H}, \mathrm{m}, \mathrm{H}-7), 3.34(1 \mathrm{H}, \mathrm{dd}, J=4.4$, $11.2 \mathrm{~Hz}, \mathrm{H}-1), 4.70\left(2 \mathrm{H}, \mathrm{m}, \mathrm{H}_{2}-12\right) ;{ }^{13} \mathrm{C}$ NMR data, $\delta_{\mathrm{C}} 79.5(\mathrm{C}-1), 28.6(\mathrm{C}-2)$, 40.9 (C-3), 71.6 (C-4), 53.0 (C-5), 25.8 (C-6), 45.7 (C-7), 26.4 (C-8), 40.6 (C-9), 39.0 (C-10), 108.4 (C-11), 150.3 (C-12), 21.0 (C-13), 13.0 (C-14), 22.8 (C-15). HR-MS m/z 239.2010 (calcd for $\mathrm{C}_{19} \mathrm{H}_{28} \mathrm{O}_{2},[\mathrm{M}+\mathrm{H}]^{+}$239.2011).

\section{Biosynthetic experiment}

$\left[1-{ }^{13} \mathrm{C}\right]$ Glucose $\left(1 \mathrm{mg} \mathrm{m}^{-1}\right)$, sodium $\left[1-{ }^{13} \mathrm{C}\right]$ acetate $\left(1 \mathrm{mg} \mathrm{m}^{-1}\right)$ and $\left[U_{-}^{-13} \mathrm{C}_{6}\right]$ glucose $\left(1 \mathrm{mg} \mathrm{ml}^{-1}\right)$ were added to the medium $38 \mathrm{~h}$ after initiation of the fermentation at separate experiments. Production of $\mathbf{1}$ and $\mathbf{3}$ started at about $38 \mathrm{~h}$ after cultivation. After 5 days, we purified the labeled samples of $\mathbf{1}$ and $\mathbf{3}$ as above, and then subjected them to ${ }^{13} \mathrm{C}$-NMR NMR spectral analysis.

\section{Biological activity}

In vitro AR binding activity was assayed as previously reported with some modifications. ${ }^{17,18}$ In brief, $50 \mu \mathrm{g} \mathrm{ml}^{-1}$ recombinant androgen receptor C-termini protein, $2 \mathrm{~nm}\left[{ }^{3} \mathrm{H}\right]$-DHT and a test compound were mixed in a binding buffer consisting of $50 \mathrm{~mm}$ Tris- $\mathrm{HCl}(\mathrm{pH} 7.4), 800 \mathrm{~mm} \mathrm{NaCl}, 10 \%$ glycerol, $1 \mathrm{mg} \mathrm{ml}^{-1}$ bovine serum albumin and $2 \mathrm{~mm}$ DTT to give a $100 \mu \mathrm{l}$ mixture solution. The mixture was incubated at $4{ }^{\circ} \mathrm{C}$ for $3 \mathrm{~h}$, and BioGel HT (Bio-Rad Laboratories, Hercules, CA, USA) was added to the solution and further incubated on ice for $15 \mathrm{~min}$. [ ${ }^{3} \mathrm{H}$ ]-DHT-bound BioGel HT was washed with washing buffer ( 40 mm Tris-HCl (pH 7.6), 100 mм KCl, 1 mм EDTA and 1 mм EGTA) three times, and its radioactivity was measured by a liquid scintillation counter.

\section{ACKNOWLEDGEMENTS}

This work was supported by in part by a Grant-in-Aid for Scientific Research (B) to H Seto. We thank Professor T Ishikawa and Dr T Kumamoto of Chiba
University for measurements of CD and ORD spectra. We also thank Dr T Kushiro of University of Tokyo for helpful discussion on the biosynthesis of gifhornenolone.

1 Fenical, W. \& Jensen, P. R. Developing a new resource for drug discovery: marine actinomycete bacteria. Nat. Chem. Biol. 2, 666-673 (2006).

2 Bister, B. et al. Abyssomicin C-a polycyclic antibiotic from a marine Verrucosispora strain as an inhibitor of the $p$-aminobenzoic acid/tetrahydrofolate biosynthesis pathway. Angew. Chem. Int. Ed. 43, 2574-2576 (2004).

3 Riedlinger, J. et al. Abyssomicins, inhibitors of the para-aminobenzoic acid pathway produced by the marine Verrucosispora strain AB-18-032. J. Antibiot. 57, 271-279 (2004).

4 Keller, S. et al. Abyssomicins $\mathrm{G}$ and $\mathrm{H}$ and atrop-abyssomicin $\mathrm{C}$ from the marine Verrucosispora strain AB-18-032. J. Antibiot. 60, 391-394 (2007).

5 Fiedler, H. P. et al. Proximicin A, B and C, novel aminofuran antibiotic and anticancer compounds isolated from marine strains of the Actinomycete. Verrucosispora J. Antibiot. 61, 158-163 (2008).

6 Schneider, K. et al. Proximicins A, B, and C-antitumor furan analogues of netropsin from the marine Actinomycete Verrucosispora induce upregulation of p53 and the cyclin kinase inhibitor p21. Angew. Chem. Int. Ed. 47, 3258-3261 (2008).

7 Motohashi, K. et al. Studies on terpenoids produced by actinomycetes: oxaloterpins A, B, C, D and E, diterpenes from Streptomyces sp. KO-3988. J. Nat. Prod. 70, 1712-1717 (2007).

8 Motohashi, K., Sue, M., Furihata, K., Ito, S. \& Seto, H. Terpenoids produced by actinomycetes: Napyradiomycins from Streptomyces antimycoticus NT17. J. Nat. Prod. 71, 595-601 (2008).

9 Motohashi, K. Studies on terpenoids produced by actinomycetes. 5-Dimethylallylindole-3-carboxylic acid and A80915G-8"-acid produced by marine-derived Streptomyces sp. MS239. J. Antibiot. 61, 75-80 (2008).

10 Furihata, K. \& Seto, H. Constant time HMBC (CT-HMBC), a new HMBC technique useful for improving separation of cross peaks. Tetrahedron Lett. 39, 7337-7340 (1998).

11 Xu, F., Morikawa, T., Matsuda, H., Ninomiya, K. \& Yoshikawa, M. Structures of new sesquiterpenes and hepatoprotective constituents from the Egyptian herbal medicine Cyperus longus. J. Nat. Prod. 67, 569-576 (2004).

12 Kuzuyama, T. \& Seto, H. Diversity of the biosynthesis of the isoprene units. Nat. Prod. Rep. 20, 171-183 (2003).

13 Shin-ya, K., Furihata, K., Hayakawa, Y. \& Seto, H. Biosynthetic studies of naphterpin, a terpenoid metabolite of Streptomyces. Tetrahedron Lett. 31, 6025-6026 (1990).

14 Isshiki, K. et al. Biosynthesis of terpentecin. J. Antibiot. 39, 1634-1635 (1986).

15 Shiomi, K. et al. Biosynthesis of napyradiomycins. J. Antibiot. 40, 1740-1745 (1987).

16 Seto, H., Orihara, N. \& Furihata, K. Studies on the biosynthesis of terpenoids produced by actinomycetes. Part 4 . Formation of BE- 40644 by the mevalonate and nonmevaIonate pathways. Tetrahedron Lett. 39, 9497-9500 (1998).

17 Freyberger, A. \& Ahr, H. J. Development and standardization of a simple binding assay for the detection of compounds with affinity for the androgen receptor. Toxicology 195, 113-126 (2004).

18 Roselli, C. E. The effect of anabolic-androgenic steroids on aromatase activity and androgen receptor binding in the rat preoptic area. Brain Res. 792, 271-276 (1998).

Supplementary Information accompanies the paper on The Journal of Antibiotics website (http://www.nature.com/ja) 